\title{
SEKTÖREL DÜZENLEMELER VE DAVRANIŞSAL IKTTISAT: 149 SAYILI KARARIN DÜŞÜNDÜRDÜKLERİ
}

Emin KÖKSAL ${ }^{1}$

Şahin ARDIYOK ${ }^{2}$

ÖZ

Bu çalışma, tüketicilerin rasyonel davrandığı varsayımıyla tasarlanan sektörel düzenlemelerin kendisinden beklenen rekabetçi yapıy sağlama fonksiyonunu yerine getirmeyebileceğini ve toplum için firsat maliyetleri yaratabileceğini vurgulamaktadır. Çalışma bu vurguyu, BTK'nın 2009 yılında yürürlüğe girip 2016 yılında yürürlüğ̈̈ sonlanan ve kamuoyunda "149 sayılı Karar” olarak bilinen düzenlemesi üzerinden, davranışsal iktisat literatürüne dayalı sistematik eleştiriler sunarak yapmaktadır. Çalışmanın vardığ sonuçlardan ilki, söz konusu düzenlemenin tüketicilerin satın alma davranışlarını yansıtmadığına işaret etmektedir. İkincisi ise, düzenlemeye tabi olan işletmecinin, tüketicilerin yanlllıklarını kullanarak, düzenlemeyi kendi lehine çevirebileceğinin gözden kaçırıldı̆̆ını göstermektedir.

Anahtar Kelimeler: Sektörel Düzenlemeler, Rekabet, Davranışsal İktisat, Fırsat Maliyeti

JEL Kodlart: D43, L43, L51

\section{SECTOR SEPECIFIC REGULATIONS AND BEHAVIORAL ECONOMICS: REFLECTIONS ON THE DECISION NUMBERED 149}

\begin{abstract}
This paper emphasizes that designing sector specific regulations, based on the rational individual assumption, may not establish a competitive environment and it has a potential to create social opportunity cost. Based on the behavioral economics literature, the paper provides a systematic critique on the regulation of ICTA in respect of the Decision numbered 149, which entered into force in 2009 and was abolished in 2016. The primary conclusion of the paper suggests that the regulation does not reflect the real purchasing behavior of the consumers. The second conclusion indicates that while designing the regulation, possible exploitative behavior of the regulated undertaking, through using the biases of consumers, are ignored.
\end{abstract}

Keywords: Sector Specific Regulations, Antitrust, Behavioral Economics, Opportunity Cost

JEL Codes: D43, L43, L51

\footnotetext{
${ }^{1}$ Yrd. Doç. Dr., Bahçeşehir Üniversitesi, emin.koksal@eas.bau.edu.tr

2 Av., BASEAK Avukat Ortaklığı, sardiyok@baseak.com
} 


\section{GíRIŞ}

Rekabet politikalarına dayalı kamu müdahalelerinin yetersiz kaldığı ve kalıcı piyasa aksaklıkları sebebiyle öncül düzenlemelere gerek duyulduğu pazarlardan biri de mobil iletişim hizmetleri pazarıdır. Dünyanın birçok ülkesinde, teknik ve ekonomik kısıtlar sebebiyle, az sayıda işletmecinin faaliyet gösterdiği ve iktisadi etkinlik açısından da az sayıda işletmecinin iyi olduğu kanısı yaygın olan bu tür pazarlarda, düzenlemeler etkin rekabetin sağlanması için kilit bir öneme sahiptir. Faaliyet gösteren işletmeler ve pazar hakkında derin ve detaylı bilgiye sahip olmanın gerekmesi sebebiyle de sektöre özgü düzenleyici otoritelerin varlığı gereklidir. $\mathrm{Bu}$ düzenleyici otoritelerden beklenen ise düzenlemeler yoluyla sektördeki kalıcı piyasa aksaklıklarını gidererek, sektörü rekabetçi bir yapıya ulaştırmasıdır.

Türkiye'de telekomünikasyon alanındaki yasal altyapının yeniden ele alınması ve düzenleyici otorite Bilgi Teknolojileri ve İletişim Kurumu'nun (BTK) kurulmasıyla birlikte elektronik haberleşme sektörü hızlı bir değişim sürecine girmiştir. Mobil iletişim hizmetleri pazarı gerek pazar yapısındaki değişim, gerekse ortaya çıkan performans açısından değerlendirildiğinde tatmin edici ilerlemelerin sağlandığı pazarlardan biridir. BTK, özellikle sunulan hizmetlerin kalitesindeki artış ve yeni teknolojilerin adapte edilme süreçlerinde öncü rol oynamıştır. Ancak yapılan bazı düzenlemelerin, tasarımı, etkinliği ve yarattığı fırsat maliyetleri açısından tartışılması faydalı olacaktır.

Bu çalışma genel olarak etkin rekabetin tesisini hedefleyen sektöre özgü düzenlemeler tasarlanırken, tüketicileri salt rasyonel bireyler olarak varsaymanın ve onların algıları ile hareket ettiği gerçeğini göz ardı etmenin, düzenlemelerin etkinliğine gölge düşürdüğünü vurgulamaktadır. Çalışma özel olarak BTK'nın 2009, 2011 ve 2012 yıllarında aldığı ve kamuoyunda "149 sayılı karar" olarak bilinen bir dizi Kurul kararına dayanan düzenlemenin tasarımının yarattığı olası firsat maliyetlerine odaklanmaktadır. Söz konusu Kurul kararları mobil iletişim hizmetleri pazarının perakende seviyesinde önemli pazar gücüne sahip olan ${ }^{3}$ işletmeci Turkcell'in sahip olduğu şebeke etkisine dayalı gücünü azaltmak amacıyla, şebeke içi ses hizmeti için uygulanan fiyat ile diğer işletmelere uygulanan arabağlantı ücretleri arasında bağ kuran bir kısıtlama olarak tasarlanmıştır. Ancak bu düzenlemenin tasarımında ve uygulamasında tüketicilerin algıları ve yanlılıkları (biases) göz ardı edilmiştir. Bu çalışma davranışsal iktisat literatürüne dayalı olarak söz konusu tasarım ve uygulamanın neden etkinsiz bir uygulama olabileceğine işaret etme amacındadır. Çalışmanın ortaya koyduğu sonuçlar

\footnotetext{
${ }^{3}$ Rekabet Kurulu'nun 23.12.2009 tarih ve 06-90/1490-379 sayılı kararında Turkcell'in perakende “GSM hizmetleri pazarında” hâkim
} durumda bulunduğu tespiti yapılmıştır. 
sadece sektörel düzenlemeler için değil, rekabet politikalarının tasarımı ve uygulanması için de davranışsal iktisadın sunduğu eleştirilerin dikkate alınmasının önemini vurgulamaktadır.

Çalışmanın ilk bölümünde ilgili düzenlemenin amacı, düzenlemeye neden gerek duyulduğu ve zaman içerisinde uygulama çerçevesinde gerçekleştirilen değişikler detaylı bir biçimde anlatılacaktır. İkinci bölümde ise, davranışsal iktisat literatüründen yola çıkarak tüketicilerin salt rasyonel bir şekilde davranmadıkları, sunulan alternatiflere bağlı olarak karar aldıklarına dair teorik ve deneysel literatür özetlenecektir. Üçüncü bölüm ise, söz konusu düzenlemenin davranışsal iktisat literatürü göz önüne alınarak yorumlanmasına ayrılmıştır. Sonuç bölümünde ise, tüketicilerin satın alma davranışlarında algının rolünün düzenleyici tarafından göz ardı edilmesinin olası etkileri değerlendirilecektir.

\section{149 SAYILI KARAR VE GELISŞİII}

Mobil iletişim hizmetleri pazarında kalıcı piyasa aksaklıkları ${ }^{4}$ sebebiyle sağlıklı bir rekabetin pazar dinamikleri yoluyla kendiliğinden oluşması çoğu zaman beklenmez ve düzenleyici otoritelerin belli politikalar çerçevesinde müdahaleleri gerekir. Türkiye'deki mobil iletişim hizmetleri pazarı birçok ülkede olduğu gibi yüksek yoğunlaşmanın olduğu bir pazardır. Ancak, Türkiye pazarını diğer birçok ülke pazarlarından ayıran en önemli özelliği pazara ilk giren Turkcell'in bazı stratejiler ile kendisine rekabetçi bir üstünlük yaratmasıdır. Turkcell, tarifelere dayalı şebeke etkilerini ve diğer işletmecilerin karşılaştığı geçiş maliyetlerini etkin bir şekilde kullanarak rakiplerine oranla daha güçlü bir konuma gelmiş ve uzun dönemli olarak pazardaki asimetrik pazar paylarının temelini atmıştır (Atiyas \& Doğan, 2007). Bu bölümde BTK'nın pazardaki rekabeti tesis etmek gayesiyle yaptığg düzenlemelerden biri olan 149 sayılı Karar’a dayalı düzenlemenin amacı, geçirdiği evrim ve uygulama şekli kısaca anlatılacaktır.

\subsection{Düzenlemenin Amacı}

Türkiye' deki mobil iletişim pazarında işletmeciler arası asimetrik pazar paylarının temel sebebi olarak Turkcell'in sahip olduğu ilk giren avantajı, pazardaki şebeke etkileri ve bununla bağlantılı geçiş maliyetleri olduğu ifade edilmişti. Ancak, bu etkileri şiddetlendiren ve kalıcı kılan diğer unsur lider işletmeci olarak Turkcell'in uyguladığg fiyatlandırma stratejileridir. 149 sayılı Karar'a dayalı düzenlemenin amacının anlaşılması için bu hususun ortaya koyulması önemlidir. Mobil iletişim hizmetlerinde işletmeciler hem kendi aboneleri hem de diğer işletmeciler için hizmet fiyatları belirlerler. Örneğin, kendi aboneleri için hem şebeke-içi hem de şebeke-dışı görüşme ücretleri belirlerken, diğer işletmecilerin abonelerinin kendi

\footnotetext{
${ }^{4}$ Şebeke etkileri, geçiş maliyetleri vb. kalıcı piyasa aksaklıkları olarak sayılabilir.
} 
şebekelerinde sonlanacak çağrıları için de çağrı sonlandırma ücretlerini belirlerler. Ücretleri belirlenen pazarlar her ne kadar birbirlerinden ayrı pazarlar gibi görünse de işletmeciler bu ücretlerin belirlenmesinde stratejik bir fiyatlama davranışı benimserler. $\mathrm{Bu}$ tür stratejik fiyatlama davranışları da genelde şebeke etkilerinin şiddetini arttırarak daha büyük pazar payına sahip işletmecinin hakimiyetini arttırmasına yol açar. İlgili literatürde bu durum tarifeye dayalı şebeke etkileri olarak adlandırılır. ${ }^{5}$

Konunun daha iyi anlaşılması için hipotetik bir örnek vermek gerekirse, asimetrik pazar paylarının söz konusu olduğu bir pazarda lider işletmeci kendi aboneleri için şebeke-içi görüşmelerin ücretlerini düşük, şebeke-dış1 görüşmelerin ücretlerini yüksek tutarak görüşme trafiğinin büyük bir kısmını kendi şebekesi içerisinde tutma eğiliminde olacaktır. Öte yandan, diğer işletmecilerden kendi abonelerine yapılan çağrıları sonlandırmak için de oluşan yüksek talebi göz önüne alarak, çağrı sonlandırma ücretlerini yükseltme eğiliminde olacaktır. ${ }^{6}$ Lider işletmecinin bu eğilimleri de şebeke dışsallıkları gibi piyasa aksaklıklarını kalıcı hale getirerek pazarda rekabetin gelişmesini engelleyecektir.

$\mathrm{Bu}$ gibi durumlarda ancak düzenleyici otoritenin öncül müdahaleleri ile işletmecilerin bu eğilimleri dizginlenip, pazarda rekabetin gelişmesinin önü açılabilecektir. Bu çalışmanın konusunu oluşturan 149 sayılı Karar'a dayalı düzenleme de bu tür bir gaye ile hazırlanan bir düzenlemedir. İncelenen dönem itibariyle, abone sayısı ve trafik açısından pazarda açık ara lider konumunda olan Turkcell'in şebeke-içi görüşme ücretleri ile çağrı sonlandırma ücretleri arasında bir bağ kurarak, Turkcell'in şebeke etkilerinden kaynaklı gücünü dizginlemeyi ve bu yolla rekabeti geliştirmeyi amaçlamaktadır.

Bu noktada, Türkiye'deki bu düzenlemeyi Avrupa Birliği (AB) ve üye ülkelerdeki düzenlemeler ile karşılaştırmak faydalı olacaktır. Mehaz AB uygulamasında ve AB üye ülkelerinde, mobil iletişim pazarlarına yönelik diğer öncül düzenlemelerin pazardaki rekabetçi endişeleri gidermekte yeterli olacağı kabul edilmektedir. Ancak Türkiye pazarında, Turkcell'in yüksek pazar gücünden ve Sanal Mobil Şebeke İşletmecilerinin (SMŞṠ) pazara girişini engelleyen çifte hazine payı düzenlemesinden ${ }^{7}$ kaynaklanan özel durum sebebiyle ilave bir müdahale ihtiyacı doğmuştur.

\footnotetext{
${ }^{5}$ Konu ile ilgili formel bir yaklaşım için bknz. (Laffont, Rey, \& Tirole, 1998).

${ }^{6} \mathrm{Bu}$ örneklerin asimetrik şebekeler açısından teorik olarak incelemeleri için bknz. (Gabrielsen \& Vagstad, 2008); (López \& Rey, 2016).

${ }^{7}$ Ülkemizde SMŞİ'lerin aktif olarak faaliyet gösterememesinin temel sebebinin yasal düzenlemeler olduğu değerlendirilmektedir. Nitekim, 406 sayılı Telgraf ve Telefon Kanunu'na eklenen Ek Madde 37 ulusal çapta kamuya açık mobil elektronik haberleşme hizmeti sunmak üzere yetkilendirilen işletmecilerin aylık brüt satışlarının belirli bir kısmını hazine payı olarak ödemelerini düzenlemektedir. Söz konusu hüküm değerlendirildiğinde, SMŞ่'l'lerin toptan mobil iletişim hizmeti aldığ işletmeci, hazine payı olarak aylık brüt satışının \%15'ini öderken, SMŞI de abonelerine sunduğu perakende hizmet için aynı oranda bir hazine payı ödeyecektir. Mevcut düzenlemeler ile, SMŞI'ler bakımından mevzuattan kaynaklanan bir piyasa aksaklığı yaratılmıştır. Şöyle ki bu durumda pazarda faaliyet gösteren bir SMŞI'nin toptan pazarda erişim yoluyla girdi aldığı rakibine oranla, perakende pazarda \%15 gibi önemli bir maliyet dezavantajına sahip olacağı görülmektedir.
} 
$\mathrm{AB}$ üye ülkelerinde Komisyon'un önerileri ${ }^{8}$ doğrultusunda mobil çağrı sonlandırma ücretlerinin Pure LRIC yöntemine ${ }^{9}$ göre belirlenmesi, mobil iletişim pazarındaki rekabetin tesisi için yeterli görülmektedir. Nitekim, çağrı sonlandırma ücretlerinin Pure LRIC yöntemine göre belirlendiği bir kurguda şebeke içi görüşmelerin fiyatının bu ücretin altına indirilmesi önemli zararlara yol açabilecektir ve Turkcell kadar yüksek pazar gücüne sahip olmayan ve diğer işletmecilerin yanı sıra SMŞİ'lerle de rekabet etmek durumunda olan bir işletmecinin bu zararlara katlanması mümkün olmayacaktır. Ancak Turkcell'in pazardaki konumu, hem bu tip uygulamalara daha uzun süre katlanabilmesini olanaklı kılmakta hem de bu uygulamaların başarıya ulaşma ihtimalini ciddi derecede arttırmaktadır. Dolayısıyla Türkiye'deki pazar yapısının 149 sayılı kararı iktisadi bakımdan meşrulaştırabileceği düşünülmektedir.

\subsection{Düzenlemenin İçeriği, Evrimi Ve Uygulama Şekli}

Öncelikle belirtmek gerekir ki, 149 sayılı Karar'a dayalı düzenleme, Türkiye'deki mobil iletişim pazarındaki rekabetin tesis edilmesi için BTK'nın toptan mobil çağrı sonlandırma hizmetlerinde etkin piyasa gücüne, perakende mobil iletişim hizmetlerinde ise önemli derecede pazar gücüne sahip Turkcell'in şebeke etkilerine dayalı gücünü sınırlama amacını taşıyan bir dizi düzenlemenin parçası niteliğindedir. BTK, mobil şebekeler arası geçiş maliyetlerinin azaltılması amacıyla uygulamaya soktuğu numara taşıma uygulaması, şebeke içi ve dış1 görüşmelere getirdiği tavan fiyat uygulamaları ve ara bağlantı ücretleri düzenlemesi diğer önemli düzenlemeler olarak sayılabilir. ${ }^{10}$ Bu sebeple hem tasarımı hem de etkileri açısından 149 sayılı Karar'a dayalı düzenlemenin tek başına bir düzenleyici uygulama olarak düşünülmemesi gerekmektedir. Bu çalışma da zaten 149 sayılı Karar'ın uygulanmasının pazarda yaptığı etkiden ziyade, uygulamanın rekabetin sağlanması konusundaki potansiyel etkinliğini tartışmayı hedeflemektedir.

İlk hayata geçirilmesi 25.03.2009 tarihindeki 2009/DK-07/149 sayılı BTK Kurul karar1 $^{11}$ ile olan ve bu sebeple de 149 nolu Karar olarak anılan uygulamaya dair ilgili metin,

\footnotetext{
${ }^{8}$ Avrupa Komisyonu'nun 07.05.2009 tarihli AB'de Sabit ve Mobil Sonlandırma Ücretlendirmelerine Yönelik Önerisi. Erişim Tarihi: 09.05.2017, http://ec.europa.eu/smart-regulation/impact/ia_carried_out/docs/ia_2009/c_2009_3359_en.pdf.

${ }^{9}$ Pure LRIC yönteminde arabağlantı ücretleri belirlenirken yalnızca arabağlantı hizmetlerinin sunulmasıyla artan maliyetlerin dikkate alınması ve ortak maliyetlerin bu hesaba dahil edilmemesi esastır. Komisyon çağrı sonlandırma hizmeti dolayısıyla artan maliyetlerin neler olduğuna da değinmektedir. Buna göre, genel maliyetler öncelikle trafikle ilgili olanlar ve olmayanlar olmak üzere ikiye ayrılmakta ve arabağlantı ücretlerinin belirlenmesi açısından sadece trafikle doğrudan ilgili maliyetler dikkate alınmaktadır.

${ }^{10}$ Bu hususların kapsamlı anlatımı için bknz.(Kulalı \& Bilir, 2012).

${ }^{11}$ Bilgi Teknolojileri İletişim Kurulu'nun 25.03.2009 tarihli ve 2009/DK-07/149 sayılı kararı, Erişim Tarihi: 20.02.2017,

https://www.btk.gov.tr/File/?path=ROOT\%2F1\%2FDocuments\%2FKurul+Karar1\%2FGSMSonKullaniciTarifeleriInceleme.pdf.
} 
“(...) Turkcell’in diğer işletmecilere uyguladı̆̆ dakika başına ă̆ırlıklı ortalama çăgrı sonlandırma ücretinin (toptan ücretin), her bir abonelik paketi bazında kullanıma bağlı olarak ortaya çıkan dakika başına ortalama şebeke içi tarifeleri (perakende ücreti) geçmemesinin sağlanmasına yönelik tedbirlerin Turkcell tarafindan alınmasinın gerekli olduğu, '

şeklindedir. ${ }^{12}$

Daha sonra 25.04.2012 tarihli ve 2012/DK-07/181 sayılı başka bir Kurul kararıyla, ${ }^{13}$ kampanya olarak nitelendirilebilecek geçici tarife değişikliklerinin de bu kapsam içine alınmasına karar verilmiştir. Ardından 13.03.2013 tarihli ve 2013/DK-ETD/142 sayılı kararlaysa, ${ }^{14}$ uygulamanın kapsamı konuşma ücretlerinin yanında kısa mesaj (SMS) ücretlerini de kapsayacak şekilde genişletilmiş, ancak Turkcell'in abonelerine sunduğu kampanyaları kapsayan yükümlülüğü askıya alınmıştır. 06.01.2014 tarihli 2014/DK-ETD/21 sayılı kurul kararı ile, ${ }^{15}$ askıya alınan kampanyalara dair yükümlülüğün 01.02.2014 tarihi itibarıyla tekrar uygulanmaya başlanmasına karar verilmiştir. Son olarak ise, 16.08.2016 tarihli ve 2016/DKETD/370 sayılı kararla ${ }^{16}$ ise uygulamanın tamamen sona erdirilmesine karar verilmiştir.

Böylelikle düzenleme 7,5 yıla yakın bir süre yürürlükte kalmış, kimi zaman kapsamı genişlemiş kimi zaman ise geçici olarak daralmıştır. Ancak düzenlemede değişmeyen ve bu çalışmanın da odağını oluşturan nokta, düzenlemenin tasarımına dayanan uygulama şeklidir. 149 sayılı Karar'da ve takip eden kararlarda yazdığı şekliyle, şebeke-içi ortalama konuşma ücretleri abonelik paketlerinin içeriği değil, abonelerin kullanım miktarı dikkat alınarak hesaplanmaktadır. Bir başka değişle BTK düzenlemede, tüketicilerin satın alma tercihlerini, onların bütçelerine dair ilişkileri ve mobil işletmecinin elde ettiği geliri bir kenara bırakarak sadece gerçekleşen tüketim miktarına bağlı bir anlayışı benimsemiştir. Takip eden bölümlerde bu tür bir tasarımın, rekabetin sağlanmasının önünde nasıl engel oluşturabileceği ve ne tür fırsat maliyetleri yaratabileceği davranışsal iktisat literatürü çerçevesinde ortaya koyulmaya çalışılacaktır.

\footnotetext{
${ }^{12}$ Bilgi Teknolojileri İletișim Kurulu'nun 16.11.2011 tarihli ve 2011/DK-07/593 sayılı kararı. Erișim Tarihi: 20.02.2017, https://www.btk.gov.tr/File/?path=ROOT\%2f1\%2fDocuments\%2fKurul+Karar1\%2f2011\%20DK\%2D07\%2D593.pdf. ${ }_{13}$ Bilgi Teknolojileri İletişim Kurulu'nun 25.04.2012 tarihli ve 2012/DK-07/181 sayılı kararı. Erişim Tarihi: 20.02.2017, https://www.btk.gov.tr/File/?path=ROOT\%2F1\%2FDocuments\%2FKurul+Karar1\%2F2012\%20DK-07-181.pdf.

${ }^{14}$ Bilgi Teknolojileri İletişim Kurulu'nun 13.03.2013 tarihli ve 2013/DK-ETD/142 sayılı kararı. Erişim Tarihi: 20.02.2017, https://www.btk.gov.tr/File/?path=ROOT\%2f1\%2fDocuments\%2fKurul+Karar1\%2f2013\%20DK\%2DETD\%2D142.pdf.

${ }_{15}^{15}$ Bilgi Teknolojileri İletişim Kurulu'nun 06.01.2014 tarihli ve 2014/DK-ETD/21 sayılı kararı. Erişim Tarihi: 20.02.2017, https://www.btk.gov.tr/File/?path=ROOT\%2f1\%2fDocuments\%2fKurul+Karar \% 2 f2014\%20DK\%2DETD\%2D21.pdf.

${ }^{16}$ Bilgi Teknolojileri İletişim Kurulu'nun 16.08.2016 tarihli ve 2016/DK-ETD/370 sayılı kararı, Erişim Tarihi: 20.02.2017, https://www.btk.gov.tr/File/?path=ROOT\%2F1\%2FDocuments\%2FKurul+Karar1\%2FTarife+Duzenlemelerinin+Degerlendirilmesi_16_08_2 016.pdf.
} 


\section{DAVRANIŞSAL İKTİSAT VE TÜKETİCİ ALGISI}

Ana akım iktisadın temel varsayımlarından biri olan "rasyonel birey" kavramını sistematik bir şekilde eleştiren bir hareket olarak ortaya çıkan davranışsal iktisat, son yıllarda kayda değer bir gelişme göstermiştir. Özellikle, Kahneman, Tversky, Thaler, ve Ariely gibi yazarların ${ }^{17}$ hem teorik hem de ampirik katkıları sayesinde davranışsal iktisat bugün disiplin halini almıştır. Bu bölümde ana hatlarıyla tüketicilerin rasyonel davrandığı varsayımına karşı eleştiriler ilgili literatüre dayalı bir şekilde özetlenecektir. Bu anlamda 3. bölümdeki asıl tartışmanın da çerçevesi çizilmiş olacaktır.

Ana akım iktisadın tüketiciler hakkındaki temel varsayımı tüketicilerin sahip oldukları bilgi çerçevesinde elde edebilecekleri en yüksek tatmin düzeyini sağlayacak kararları rasyonel bir biçimde aldıkları yönündedir. Örneğin tüketicilerin içinde bulundukları durumdan ya da sunulan bağlamdan bağımsız bir şekilde karar verdikleri varsayılmaktadır. Ya da tüketicilerin geçmişteki tecrübelerini hatırladığı ve bunlardan elde ettiği bilgileri de kullanarak rasyonel tercihler yaptığı öngörülmektedir. Bunun yanında, tüketicilerin zamana yayılan tercihleri konusunda da tutarlı davrandıkları kabul edilmektedir.

Oysa yukarıda sayılan üç saptamaya dayalı öngörülerin gerçek hayatta tüketicilerin tercihleri ile bağdaşmadığı davranışsal iktisat çerçevesinde yapılan çalışmalar sayesinde sistematik bir şekilde ortaya konulmuştur. Tüketicilerin rasyonellikten uzak ve yanlılıklar barındıran bu tercihleri yapmalarına sebep olan etkilerin incelenmesi bu anlamda oldukça önemlidir.

\subsection{Bağlam Etkisi}

Geleneksel tüketici tercihi yaklaşımı, tüketicilerin davranışlarını incelerken bunların sunulduğu ortamdan ve sunuş şeklinden bağımsız olduğunu, bu farklılıkların tüketiciler tarafından algılandığını ve buna göre tercihlerin yapıldığını varsaymaktadır. Oysa gerçek yaşamda bunun böyle olmadığı, tüketicilerin ürün ya da hizmetin sunum şeklinden tutun, sunulan mekânın bile tüketicilerin tercihlerinde farklılık yarattığı bilinmektedir. Çerçeveleme etkisi olarak adlandırabilecek bu etkinin tüketicilerin tercihleri üzerinde sistematik etkiler yarattığı Tversky \& Kahneman (1981)'den bu yana bilinmektedir.

Örneğin indirimlerin yüzde olarak değil de para miktarı olarak sunulduğu (DelVecchio, Krishnan, \& Smith, 2007), iki üründen birinin bedava olarak lanse edildiği (Li, Sun, \& Wang,

\footnotetext{
${ }^{17} \mathrm{Bu}$ yazarların özgün katkılarına çalışmanın ilerleyen kısımlarında ayrıca yer verilecektir.
} 
2007), ya da bir kaybın pozitif bir şekilde ifade edildiği (Levin, Wall, Dolezal, \& Norman, 1973) durumlarda tüketicilerin öngörülen rasyonel tercihlerden uzaklaştı̆̆ görülmektedir. Dolayısıyla tüketicilerin tercihlerinin sunulan çerçeveden bağımsız olmadı̆̆ sistematik bir durum arz ettiği gerek teorik gerekse ampirik kanıtlar ile ortaya konulmuştur.

Bunun yanında, tüketicilerin tercihlerinde bir çapa etkisinin varlığından da bahsetmek gerekir. Bir tür çerçeveleme etkisi olarak ifade edilen bu yanlılık, tüketicilerin kendilerine sunulan bir referans noktası ya da bir çapadan yola çıkarak karar verdiklerini ortaya koymaktadır (Tversky \& Kahneman, 1974). Hatta bu referans noktasının gerçeklikten uzak olması durumunda dahi tüketici tercihlerinin etkilendiği ortaya koyulmuştur (Ariely, Loewenstein, \& Prelec, 2003). Örneğin fiyat karşılaştırmalarına dair internet sitelerinde listenin en başına koyulan bir ürünün fiyatının, alttaki ürünlerden farklı olmamasına rağmen daha çok değer atfettikleri görülmüştür (Armstrong, 2008).

Çerçeveleme etkisi altında incelenebilecek bir başka tüketici yanlılığı ise, sahiplik (endowment) etkisidir. Klasik tüketici tercihi teorisinde, tüketicilerin aynı fayda düzeyini sağlanması durumunda farklı tüketim sepetleri arasında kayıtsız kaldıkları varsayılır. Oysa tüketicilerin pek de böyle davranmadıkları bilinmektedir. Kahneman, Knetsch, \& Thaler (1990, 1991) tüketicilerin sepetlerindeki ürün bileşiminin değişiminde, özellikle bir ürünün azalıyor olmasından hoşnut olmadıklarını göstermektedir. Daha açık bir ifadeyle, tüketiciler sepetlerindeki bir malın miktarının azalmasını -diğer bir malın miktarındaki artışa rağmenmemnuniyetsizlikle karşılamaktadır.

Bu noktada sahiplik etkisi ile bağlantılı bir başka yanlılıktan daha bahsetmek gerekir. Tüketicilerin hâlihazırda sahip oldukları ürüne daha çok değer atfettiği ancak aynı değeri edinilecek bir diğer ürüne vermediği görülmektedir (Samuelson \& Zeckhauser, 1988). Statükoculuk olarak adlandırılan bu yanlılık, mevcut durumu ve dolayısıyla tüketicilerin önceden yapmış olduğu tercihleri muhafaza eden bir duruma işaret etmektedir.

\subsection{Belirsizlik Etkisi}

Bir olayın gerçekleşeme olasılığı ve buna dair beklentiler tüm iktisadi birimlerin karar süreçlerinde önemli bir rol oynar. Ana akım iktisadın bu süreçler için varsaydığ 1 davranış biçimlerinin temel aldığı yöntemler, istatistiksel örneklemlere ve Bayes Kuralı olarak bilinen yeni bilgilerin 1şı̆ğ altında bir olayın olma olasılığının güncellenmesi prensibine dayanmaktadır. Fakat yapılan çalışmalar bireylerin aldığı kararların bu temel prensipleri ihlal eder nitelikte olduğuna işaret etmektedir. Örneğin bireyler bir olayın olma olasılığının, olayı 
hayal etmenin kolay olması ya da olayın daha önce olmuş bir olayı hatırlatması durumunda daha yüksek olduğunu, diğer hallerde ise daha düşük olduğunu düşünmektedir (Kahneman \& Frederick, 2002).

Yukarda örneği verilen yanlılıkla ilintili bir şekilde, bireyler kendilerinin ya da yakınlarının göreceli olarak küçük sayıdaki deneyimlerinden yola çıkarak, büyük genellemeler yapma eğilimindedir. Daha teknik bir deyişle, bireyler niceliksel iktisadın dayandığı temel bilimlerden biri olan istatistikteki büyük sayılar kuralının ${ }^{18}$ tersine, genellemelerini küçük sayılar kuralına dayanarak yapmaktadır. Yani, belirsizlik altında genellikle kendi yaşadıkları ya da şahit oldukları deneyimlerden yola çıkarak kararlarını almaktadır (Tversky \& Kahneman, 1971). Bu durum bize, bireylerin bir olayın gerçekleşme olasılığının kendilerinin zannettiği gibi dağıldığını varsaydığını ve dağılım içindeki farklılıkları görmezden geldiğini göstermektedir.

Belirsizlik etkisi başlığı altındaki bir başka yanlılık ise, bireylerin rastlantısal olaylar için olan algısıdır. Bu konuda yapılan çalışmalar bireylerin rastlantısallığı algılamakta ve tercihlerini yaparken bunu dikkate almakta zorlandığını göstermektedir (Gilovich, Vallone, \& Tversky, 1985). Bunun da ötesinde bazı araştırmalar, bireylerin rastlantısal olmayan olayları da algılamakta güçlük çektiğine işaret etmektedir (Hsu, Huang, \& Tang, 2007). Bununla ilintili bir şekilde, bireyler geçmişteki yaptıkları iyi şeyleri hatırlayıp kötü şeyleri unutma eğilimindedir.

\subsection{Zamana Yayılan Kararlardaki Yanlılıklar}

Geleneksel iktisat teorisi, tüketicilerin zamana dayalı kararlarını, her bir zaman dilimi için elde edecekleri faydanın bugünkü değerini hesaplayarak aldığını öngörmektedir. Oysa, yapılan çalışmalar tüketicilerin pek de böyle davranmadığını, yukarıda bahsedilen yanlılıkların benzerlerinin bireylerin zamana yayılan kararlarında da var olduğunu göstermektedir (Frederick, Loewenstein, \& O’Donoghue, 2002).

$\mathrm{Bu}$ yanlılıkların en önemlisi tüketicilerin gelecekteki tüketimlerinden elde edecekleri faydayı bugüne indirgediklerindeki algılarına dayalıdır. Standart iktisat modellerinde, tüketicilerin sonraki zamanlar için elde edecekleri faydayı bugünkü faydaya indirgerken sabit bir üstel (exponential) oranında indirgediği varsayılır. Bu varsayım bir yandan modeli matematiksel açıdan daha basit kılarken diğer yandan da tüketicilerin zamanlar arasında tutarlı bir davranış sergilediğine işaret etmektedir. Daha teknik bir deyişle, her bir zaman diliminde

\footnotetext{
${ }^{18}$ Büyük sayılar kuralı, bir popülasyon içinden seçilen örneklemin büyüklüğü arttıkça bu örneklemden elde edilecek ortalamanın popülasyonun ortalamasına yakınsayacağına işaret eder.
} 
tüketicilerin şimdi ya da gelecekteki tüketimleri arasındaki ikame oranının sabit olduğuna işaret etmektedir.

Fakat yapılan ampirik çalışmalar tüketicilerin zamana dayalı tercihlerinde bu türden bir sabit indirgeme oranını düşünmediğini göstermektedir (Thaler, 1981). Ampirik çalışmalardan elde edilin verilerde, üstel bir fonksiyon yerine hiperbolik bir fonksiyonun gerçekteki indirgeme davranışını daha iyi açıkladığı ortaya konmuştur (Laibson, 1997). Hiperbolik bir indirgeme fonksiyonunda, tüketicilerin zamanlar arası ikame oranı birbirinin aynı değildir. Tüketici uzak gelecekteki elde edeceği faydayı daha büyük oranda indirgerken yakın gelecekte elde edeceği faydayı göreli olarak daha küçük oranda indirger.

$\mathrm{Bu}$ durum da tüketicinin zamanlar arası bir tutarsızlık içinde davrandığını ortaya koymaktadır. Pratikte bu durum, tüketicilerin maliyetleri ve getirileri uzak gelecekte olan kararları daha sağduyulu bir şekilde planlayarak aldığına, fakat bu maliyet ve getiriler zaman açısından yakınlaştıkça yaptıkları planlama ve kararlardan uzaklaştığı bir duruma işaret etmektedir. Daha genel bir ifadeyle, tüketiciler gelecekte gerçekleştirecekleri eylemler konusunda rasyonel kararlar verirken, o gün geldiğinde karşılaşacakları anlık maliyetleri düşünerek bu kararlarından vazgeçebilmektedir. Böylelikle de farklı zamanlar arasında tutarsız davranmaktadir.

Bireylerin karşılaştı̆̆ birçok kararın zamana yayılan kararlar olduğu düşünüldüğünde, sözü edilen tutarsızlığın karmaşık sorunlara yol açtığg da tahmin edilebilecektir. Bu çalışma açısından da özel bir öneme sahip olan bireylerin kendini kontrol etme (self-control) sorunu zamana yayılan karar ve eylemler söz konusu olduğunda ortaya çıkabilecek bir yanlılıktır. Örneğin spor, diyet, yatırım, uzun dönemli üyelikler/abonelikler, maliyet ve getirileri farklı zamanlara yayılan aktivitelerdir. Bugün yapılan bir spor ya da diyetin maliyetine bugünden itibaren katlanılmaya başlanırken, getirileri daha uzun vadede elde edilebilecektir. Hiperbolik bir şekilde indirgeme yapan bir birey için de gelecekteki getirilerin önemsiz olması sebebiyle bugünkü maliyetlere katlanmama yönünde bir tercih eğilimi ortaya çıkabilecektir.

En basit haliyle yukardaki şekilde formüle edilebilecek kendini kontrol etme problemi, uzun y1llardır davranışsal iktisatta incelenen yanlılıklardan biridir (Thaler \& Shefrin, 1981). Çalışmalarda, bireylerin bu problemlerinin farkında olup olmaması durumuna bağlı olarak farklı varsayımlar ve modeller kullanılmıştır. Bireylerin bu sorunlarının farkında olmaları çeşitli taahhütlerde bulunarak bu sorunun üstesinden gelmelerini sağlayabilmektedir. Hatta bu taahhütlerin bireylerin kontrolleri dışındaki unsurları (başkalarına verilen sözler, topluluk 
önünde açıklamalar, vb.) içermesinin daha etkili bir yöntem olduğu ortaya konmuştur (Ariely \& Wertenbroch, 2002).

$\mathrm{Bu}$ konudaki ampirik çalışmalardan biri spor salonlarına üyelikler üzerine yapılan çalışmadır (Della Vigna \& Malmendier, 2006). Ayrıca bu çalışma bir sonraki bölümde yapacağımız analizler için yol gösterici niteliktedir. Çalışma, tüketicilerin peşin ödeme yaparak satın aldıkları spor salonu aylık üyeliklerini rasyonel bir şekilde kullanmadıklarını, toplam tüketimlerini tek kullanımlık ücretler şeklinde ödemelerinin daha az maliyetli olduğunu ortaya koymuştur. Çalışma, kendini kontrol etme probleminin farkında olan bireylerin bir taahhüt mekanizması yaratmak amacıyla yaptıkları peşin ödemenin beklendiği gibi bir sonuç vermediğini ortaya koyması açısından oldukça önemlidir. Yazarlar tüketicilerin bu davranışlarını, bedel bir defa ödediğinde ve salona gitme vakti geldiğinde tüketicilerin zaten katlanılmış bir maliyet için yeniden bir zahmete girmeyip gitmeme yönünde bir tercih kullandıkları şeklinde açıklamaktadır. Yazarlar ayrıca tüketicilerin üyeliklerini sona erdirmemelerini de tüketicilerin aşırı kendine güvenine ve buna dayalı olarak gelecekte bu hizmeti kullanacaklarına dair iyimserliklerine bağlamaktadır. $\mathrm{Bu}$ iki sebeple tüketiciler üyeliklerini iptal etmeyerek, atalet içinde hareket etmektedir.

Özetle, bu bölümde davranışsal iktisat literatürünün bir kısmına dayalı olarak tüketicilerin iktisat teori ve modellerinde varsayıldığı gibi rasyonel iktisadi birimler olmadığ hesap yapabilme, gerçeği algılayabilme yeteneklerinin sınırlı olduğu ortaya koyulmaya çalışılmıştır. Takip eden bölümde tüketicilerin bu tür yanlılıklarının çalışmanın konusunu oluşturan 149 sayılı Karar'a dayalı düzenleme etrafında bir incelemesi yapılacaktır.

\section{149 SAYILI KARARA DAVRANIŞSAL İKTISAT AÇISINDAN BİR BAKIŞ}

Mobil iletişim hizmetleri, hem aynı kanaldan sunulan hizmetlerin çeşitliliği (ses, kısa mesaj, veri) hem de verilen orta ve uzun vadeli taahhütler sebebiyle oldukça karmaşık bir tarife yapısına sahiptir. Bu sebeple de tüketicilerden, özellikle yukarıda sayılan yanlılıklara sahip oldukları düşünüldüğünde, kendileri için en yüksek faydayı sağlayacak tercihleri yapması beklenmez. Dolayısıyla tüketici tercihlerine dayalı, fakat tüketicilerin yanlılıklarını dikkate almayan bir düzenlemenin ya da rekabet politikası uygulamasının da amaçladığı hedeflere ulaşması düşünülemez.

Bu bölümde, Turkcell'in özellikle tarifeye dayalı şebeke dışsallığı yaratmaya yönelik stratejilerini pazarda rekabeti sağlamak adına kısıtlamayı amaçlayan 149 sayılı Karar'a dayalı düzenlemenin neden yeterince etkin olmadığı vurgulanmaya çalış1lacaktır. Bunu yaparken de 
ilk olarak, sunulan paketlerin tüketicilerin yanlılıklarını nasıl etkilediği anlatılacak, ardından da tüketicilerin zaman içinde gerçek tercihlerini öğrenmelerine rağmen sahip oldukları tarife ve paketleri değiştirmemelerinin sebepleri üzerinde durulacaktır. Son olarak ise, bu bilgilere dayanarak düzenlemenin neden etkinsiz olduğu anlatılacaktır.

\subsection{Mobil İletişim Hizmetlerindeki Karmaşık Fiyat Yapısı Ve Tüketicilerin Algısı}

Mobil iletişimde nihai hizmetlerin farklı miktar ve bileşimlerde sunuluyor olması, tüketicilerin kendileri için en iyi tercihleri yapmalarının önündeki engellerden biridir. Aslen bu durum sunulan tarife ve paketlerin karmaşıklığından değil, tüketicileri rasyonel tercihler yapmaktan alıkoyan yanlılıklardan kaynaklanmaktadır.

$\mathrm{Bu}$ yanlılıkların başında da bir önceki bölümde bahsedilen kendini kontrol etme problemi gelmektedir. Hatırlatmak gerekirse, kendini kontrol etme problemi bireylerin özellikle maliyet ve getirileri zamana yayılan tüketim kararları söz konusu olduğunda, başta öngördükleri ile zaman içinde gerçekleştirdikleri arasında farklılıkların oluşmasına dair bir soruna işaret etmektedir. Bireylerin bu durumun farkında olmaları ise, çeşitli taahhüt mekanizmaları ile onları bu problemin üstesinden gelmeye itmektedir. Bir önceki bölümde belirtilen uzun dönemli spor salonu üyeliklerine dair çalışma bunun güzel bir örneğidir. İletişim hizmetlerinde ise, kendini kontrol etme problemi ve buna dayalı bir taahhüt verme şekli ön ödemeli veya faturalı hatlar için sunulan paketlerin tercih edilmesi şeklinde ortaya çıkmaktadır. $\mathrm{Bu}$ durum, genel olarak kullanıma bağlı bir tarifenin seçilmesi ile daha az maliyete katlanılacakken, gelecekte daha çok tüketileceğini düşünerek daha yükssek hacimli veya sınırsız iletişim imkânı veren paketlerin tercih edildiği bir taahhüt mekanizması şeklinde ortaya çıkmaktadır (Lunn, 2013).

Ancak bu alanda yapılan çalışmalar (Lambrecht \& Skiera, 2006; Miravete, 2003; Pauwels \& Weiss, 2008; Train, McFadden, \& Ben-Akiva, 1987) verilen bu taahhütlerin ve dolayısıyla abone olunan tarife veya paketlerin, tüketiciler için optimal seçimler olmadığını ortaya koymaktadır. Bu noktada ilgili literatürde sıkça anılan ampirik çalışmalardan biri olan Lambrecht \& Skiera, (2006) çalışmasından bahsetmek faydalı olacaktır. Yazarlar daha önceki sabit hatlı telefonlar için abonelerin yaptığı optimal olmayan tercihlerden (Miravete, 2003; Train et al., 1987) yola çıkarak 10.000'in üzerinde tüketicinin internet kullanım ve abonelik detaylarını incelemişlerdir. Yazarların en çarpıcı bulgusu abonelerin birçoğunun kendi tüketimleri açısından yanlış tarife seçimi yaptıkları doğrultusundadır. Örneğin, sınırsız tarife abonelerinin \%20’ye yakınının, sınırlı tarife abonelerinin ise yarısından fazlasının daha düşük bir tarifeye geçerek daha az ödeyebilecekleri ortaya konmuştur. Sınırlı tarife kullanıcılarının 
sadece küçük bir kısmının daha yüksek içerikli bir pakete ya da sınırsız tarifeye geçmeleri durumunda optimal bir tercih yapabilecekleri de ortaya konulan bulgular arasındadır.

Yazarlar, abonelerin tüketimlerinden daha yüksek tarifeleri tercih etmelerinin temelinde gelecekle ilgili tüketimlerindeki belirsizlik algısının yattığını savunmuşlardır. Yazarlar bu savunmalarını üç etkiye -sigorta etkisi, aşırı tahmin etkisi ve taksimetre etkisi- dayandırarak gerekçelendirmişlerdir. Buna göre, tüketicilerin tükettiklerinden daha yüksek hacimli tarifeleri tercih etmeleri (1) yüksek faturalardan kaçınmak amacıyla sigorta olarak görmelerine, (2) gelecekteki olası tüketimlerini abartılı tahminlerine ve (3) tüketirken elde edecekleri faydayı hoşnutsuz hale getirecek fatura sürprizlerine yani taksimetre etkisine dayanmaktadır. Bütün bunların sonucunda yazarlar, özellikle yüksek hacimli tarifeleri seçen abonelerin hem kısa hem de uzun vadede bu davranışları ile işletmelerin karlarına katkı sağladığı sonucuna varmışlardır.

Kontrol etme problemi ile bağlantılı olarak abonelerin kendileri için optimal tarife ve paketleri seçememelerinin bir diğer sebebi de gelecekteki beklentiler konusunda abartılı iyimserlikler barındıran aşırı kendine güvenden kaynaklanmaktır. Bu tür bir yanlılık ile hareket eden bir tüketicinin tüketimini kendi isteği doğrultusunda arttırıp azaltacağına dair kendine aşırı bir güveni söz konusudur (DellaVigna, 2009). Bu türden bir davranış içerisindeki tüketiciler tüketim miktarlarına dair değişkenlikleri abartılı bir biçimde küçümser ya da büyütürler. $\mathrm{Bu}$ sebeple de sınırsız tarife abonesi olan ama kullanım miktarı az olan veya sınırlı tarife içerisinde olan fakat kullanım miktarı bu sınırı aşabilen tüketici tercihlerinin olduğu optimal olmayan seçimler söz konusudur (Lunn, 2013).

Bu noktada işletmecilerin, tüketicilerin bu yanlılıklarından faydalanarak nasıl karlarını arttırdıklarına de değinmek gerekir. Bu hususa değinen önemli ampirik çalışmalardan biri olan Grubb (2009) bir bölümü, tüketicilerin gerçek kullanım seviyeleri ile satın alma işlemini yaparken ki abartılı öngörüleri arasındaki farkın işletmecilerce nasıl karlarını arttıracak şekilde kullanılabileceğine işaret etmektedir. Yazar, bu tür tüketici yanlılıklarının mobil işletmecileri sıfır marjinal maliyetle sunulan hizmetlerin miktarını arttırarak artan marjinal fiyatlama yapmaya teşvik ettiğini göstermiştir.

\subsection{Tüketicilerin Kendileri İçin Optimal Tarife Ve Paketlere Geçişini Engelleyen Yanlılıklar}

Tüketicilerin optimal tarife ve paketler konusunda tercihlerini yansıtmayan seçimler yapmalarının yanında bu seçimlerini değiştirmiyor olmaları da değinilmesi gereken diğer bir önemli husustur. $\mathrm{Bu}$ noktada bir önceki bölümde bahsedilen yanlılıkların da ötesinde bazı 
tüketici algı ve davranışlarının mobil iletişim hizmetlerinin tüketimi açısından incelenmesi gerekir.

Mobil iletişim hizmetleri abonelerinin, optimal olmayan tarife ve paket seçimlerinden kendileri için en yüksek faydayı sağlayan seçimlere yönelmesinin önündeki en büyük algısal engellerden biri, bir önceki bölümde de bahsedilen sahiplik etkisidir. Hatırlanacağı gibi, sahiplik etkisi, tüketicilerin sepetlerindeki ürün bileşiminin değişiminde, özellikle bir ürünün azalıyor olmasından hoşnut olmadıkları bir duruma işaret etmektedir. Mobil iletişim hizmetlerinde abonelerin sahip oldukları tarife ya da paketler içindeki hizmetlerin miktar olarak tamamını kullanmıyor olmaları durumunda başka bir tarife ya da pakete geçerek daha az para ödeyecek olmaları kulağa oldukça rasyonel gelse de birçok saha deneyi sahiplik etkisinin aboneleri tarife ve paketlerini değiştirmekten alıkoyduğunu göstermektedir (Plott \& Zeiler, 2005). Aboneler, kendileri için daha avantajlı olan tarife veya paketlere geçerken bunların içeriklerinin azalıyor olmasından memnuniyetsizlik duymakta, bu duygu da söz konusu geçiş için bir atalet yaratmaktadır.

Sahiplik etkisi ile bağlantılı ve bu etkiyi kuvvetlendiren bir diğer önemli yanlılık da statükoculuktur. Hatırlanacağı gibi, bu yanlılık başta edinilen veya varsayılan (default) tüketimin devam ettirilmesi eğilimine işaret etmektedir. Bu yanlılık pek çok farklı sebepten kaynaklanabileceği gibi, tüketicinin yapacağ farklı bir seçimin ortaya çıkarabileceği fayda ve maliyetlerin öngörülememesinden de kaynaklanabilir. Abonelerin tarife ve paket değişiklikleri sonrasında karşılaşabilecekleri olası sorunların yarattığı algı bu çerçevede düşünülebilir. Mobil iletişim hizmetlerindeki karmaşık fiyatlama yapısı düşünüldüğünde bu etkinin varlığı inkâr edilemez duruma işaret etmektedir.

Öte yandan mobil iletişim hizmetlerinde sadece sahiplik veya statükoculuğun değil, tüketicilerin ataletinden kaynaklanan yanlılıkların da rasyonel seçimleri engellediğinden bahsetmek gerekir. Bunun temel sebebi olarak da yine bir önceki bölümde bahsettiğimiz fayda ve maliyetleri zamana yayılan kararlara dair tüketicilerin tutarsız davranışları gösterilebilir. Hatırlanacağı gibi tüketiciler, iktisadi modellerde varsayıldığı gibi farklı zaman dilimlerinde elde edecekleri fayda veya karşılaşacakları maliyetler için ikame oranını sabit olarak görmemektedirler.

Örneğin, uzak gelecekte elde edecekleri bir faydayı daha büyük oranda indirgerken, bu fayda içim yakın gelecekte karşılaşacakları maliyeti çok daha küçük oranda indirgemektedirler. 
Bu durumun pratikteki yansıması, tüketicilerin gelecekte fayda sağlayacak eylemler için başta katlanılan maliyetleri düşünerek harekete geçmemeleri ya da sürekli ertelemeleri şeklinde ortaya çıkmaktadır. Bu davranışa atfen Lambrecht \& Skiera (2006) çalışmalarında, bir tarife veya paketten başka bir tarife ya da pakete geçme işinin zahmetli olması durumunda kendileri için optimal olmayan tarife ve paketlerde kalan birçok abone olacağına işaret etmektedir.

\subsection{Sayılı Karar’a Dayalı Düzenlemenin Etkinsizliği}

Bir kısmına yukarıda da değinilen teorik ve ampirik çalışmalar, tüketicilerin kendini kontrol etme ve aşırı kendine güven yanlılıkları sebebiyle mobil işletmeciler tarafından yönlendirilebileceğini ortaya koymaktadır. Bununla birlikte tüketicilerin bulundukları tarifelerin veya abone oldukları paketlerin kendileri için optimal seçimler olmadığını bilmeleri halinde bile sahiplik etkisi, statükoculuk ve erteleme gibi yanlılıkları sebebiyle atalet içerisinde kaldığı görülmektedir.

Tüketicilerin bu tür yanlılıklara sahip olduğunun farkında olan mobil işletmeciler abonelerinin başta yaptıkları tarife/paket seçimleri ile gerçekleşen kullanım miktarları arasında kayda değer bir fark olduğunu öngörebilmekte ve karlarını maksimize edecek tarife ve paketler tasarlayabilmektedir. Aynı zamanda, tüketicilerin bulunduğu tarife ve paketlerden daha uygun olanlarına geçişlerini bu sayılan yanlılıkları kullanarak algısal olarak zorlaştırabilmektedir. Aynı yanlılıkların, düzenlemede aralarında bağ kurulan şebeke içi görüşme ücretleri ve çağrı sonlandırma ücretleri gibi, bir mobil işletmeci için diğer işletmeciler ile rekabette stratejik öneme sahip değişkenlerin yönlendirebilmesi için kullanılması da gayet olasıdır.

Tüketicilerin satın alma eylemlerini ve ödedikleri bedelleri bir tarafa bırakıp sadece kullanımlarına dayalı bir uygulama, ne tüketicilerin gerçek tercihlerini ne de bütçeleri ile olan ilişkilerini yansıtmaktadır. Düzenlemenin uygulamasında kullanım miktarının dikkate alınıyor olması, tüketicilerin gerçek tercihlerini yansıttığı düşünülse de iktisadi olarak tüketim düzeyinin ödenen bedel ve tüketici bütçesi ile ilişkilendirilmemiş olması onun optimal bir tercih olarak nitelendirilmesini engellemektedir. Çalışma boyunca ilgili literatürden örnekler ile bu tür tercihlerin neden optimal olmadığ 1 ortaya konulmuş, bu tercihleri tüketicilerin değiştirmekte neden zorlandığı da sistematik bir şekilde incelenmiştir.

Esasında mobil işletmecilerin, abonelerin sahip olduğu bu tür yanlılıklardan faydalanarak kendi karını maksimize edecek şekilde davranması doğal bir davranıştır. İşletmeciler, sahip oldukları uzun dönemli kullanım istatistiklerine dayalı analizler yardımıyla tasarladıkları tarife ve paketlerle, tüketicileri kendi çıkarları doğrultusunda 
yönlendirebilmektedir. Çağrı sonlandırma ve şebeke içi görüşme ücretleri gibi iki stratejik değişken arasında bağ kuran bir düzenlemenin de bu tür bir yönlendirmeyi mutlaka dikkate almas1 gerekir.

$\mathrm{Bu}$ anlatılanları basit bir hipotetik örnek çerçevesinde incelemek meseleyi vurgulamak açısından faydalı olacaktır. Varsayalım ki, bahsi geçen düzenlemeye tabi mobil işletmeci, abonelerine (i) 10 TL'lik 100 dakikalık, (ii) 15 TL'ye 300 dakikalık ve (iii) 20 TL'ye 500 dakikalık şebeke içi görüşme imkânı sağlayan paketler önermiş olsun. İlk paketin muhtevasına yakın (örneğin ortalama 100 dakika) şebeke içi görüşme yapan tüketicilerin fiyat ve dakika karşılaştırması yaparak, yukarıda hem teorik hem de ampirik kanıtlarıyla ortaya koyulan yanlılıkları sebebiyle, daha yüksek hacimli paketlere yönelmesi ihtimal dahilindedir. $\mathrm{Bu}$ durumda, kullanıma bağlı olarak ortaya çıkan dakika başına ortalama şebeke içi (perakende) ücret, ilgili paketler için (i) $10 \mathrm{KRŞ,} \mathrm{(ii)} 15 \mathrm{KRŞ} \mathrm{ve} \mathrm{(iii)} 20 \mathrm{KRŞ} \mathrm{olarak} \mathrm{karşımıza} \mathrm{çıkacaktır.}$ $\mathrm{Bu}$ durum düzenlemeye tabi olan işletmeciye, tarife ve paket tasarımı aracılığıyla, tüketicilerin yanlılıklarını kullanarak diğer işletmecilere uyguladığı dakika başına ağırlıklı ortalama çağrı sonlandırma (toptan) ücreti arttırma imkânı verecektir. Bu durum Tablo 1'de de özetlenmiştir.

Tablo 1: Sunulan Paketler Ve Oluşabilecek Çağrı Sonlandırma Ücretleri

\begin{tabular}{|c|c|}
\hline $\begin{array}{c}\text { Ortalama 100 dakika şebeke içi görüşme } \\
\text { yapan yanlılıklara sahip abonelere sunulan } \\
\text { tarife/paket seçenekleri }\end{array}$ & $\begin{array}{c}\text { Mobil işletmecinin uygulayabileceği } \\
\text { çağrı sonlandırma (toptan) ücreti ( } \leq \text { şebeke içi } \\
\text { ücret) }\end{array}$ \\
\hline $\mathbf{1 0} \mathbf{T L}-\mathbf{1 0 0}$ Dakika & Çağrı sonlandırma (toptan) ücret $\leq 10 \mathrm{KRŞ}$ \\
\hline $\mathbf{1 5} \mathbf{T L}-\mathbf{3 0 0}$ Dakika & Çağrı sonlandırma (toptan) ücret $\leq 15 \mathrm{KRŞ}$ \\
\hline $\mathbf{2 0} \mathbf{T L}-\mathbf{5 0 0}$ Dakika & Çağrı sonlandırma (toptan) ücret $\leq 20 \mathrm{KRŞ}$ \\
\hline
\end{tabular}

Öte yandan, 149 sayılı Karar'a ilişkin düzenlemenin pazarda yarattığı somut etkinin tartışılması gerektiği de düşünülebilir. Örneğin, düzenlemenin mobil işletmecilerin pazar paylarındaki asimetriyi giderici bir etkisinin olması beklenmektedir. Bu konuyu tartışmak amaciyla, düzenlemenin de yürürlükte olduğu zaman dilimi için Şekil 1'de mobil işletmecilerin abone sayısına göre pazar payları verilmiştir. 


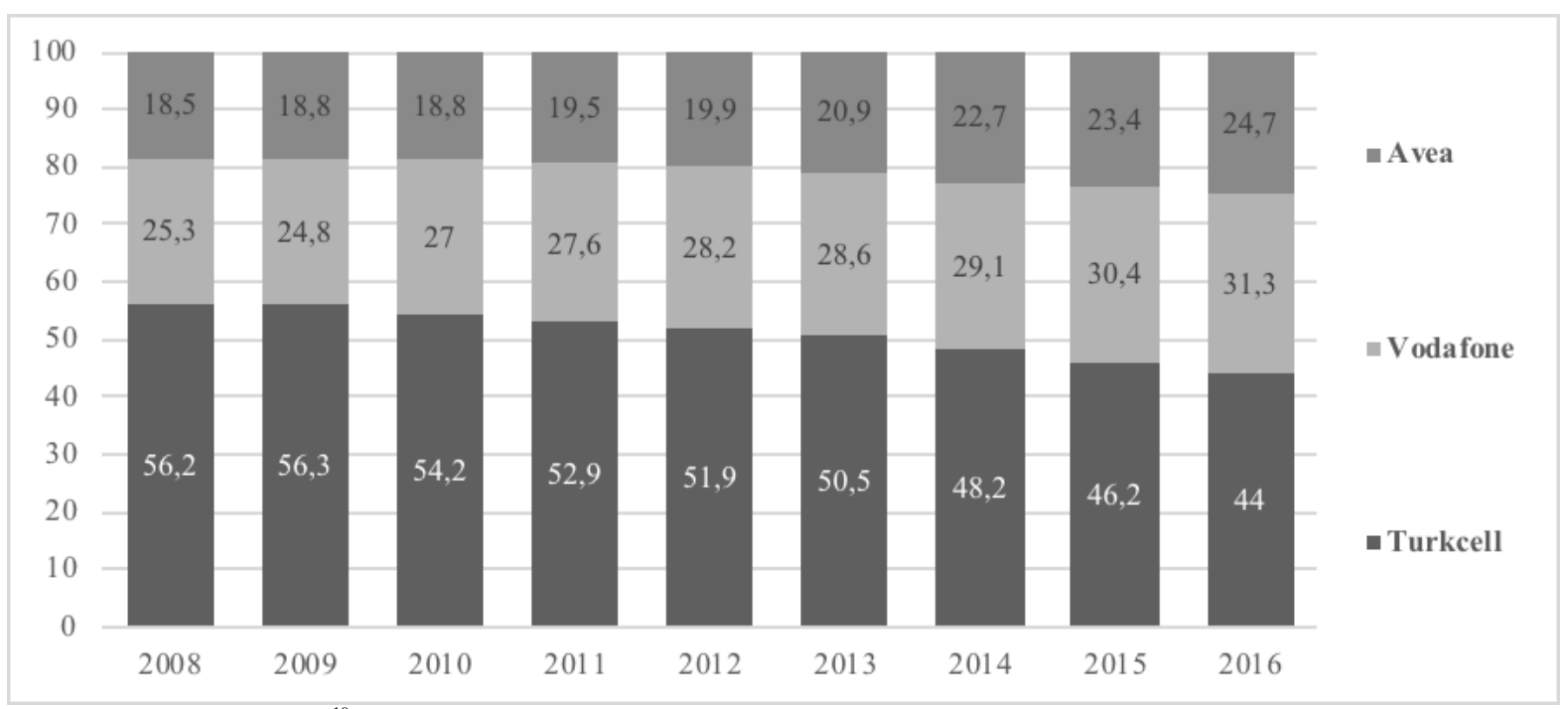

Kaynak: BTK Pazar Verileri ${ }^{19}$

Şekil 1: Mobil İşletmecilerin Abone Sayısına Göre Pazar Payları (\%)

Şekil 1'de sunulan işletmecilerin pazar paylarına dair verilere bakıldığında, 2009 sonrası dönemde Turkcell'in payı düşerken diğer işletmecilerin payları yükselmeye başlamıştır. İlk bakışta bu durum 149 sayılı Karar'ın bir etkisi gibi düşünülebilir. Fakat 2008 yılı sonu itibariyle hayata geçirilen numara taşınabilirliği düzenlemesini unutmamak gerekir. BTK verilerine göre ilk iki yıllık sürede 28 milyonun üzerinde numara taşıma işlemi gerçekleşmiştir. Bunun da ötesinde, daha önce de belirtildiği üzere, 149 sayılı Karar'a dayalı düzenleme Turkcell'in şebeke etkilerine dayalı gücünü sınırlama amacını taşıyan bir dizi düzenlemenin parçası niteliğindedir. Numara taşıma düzenlemesi dışında, şebeke içi ve dışı görüşmelere getirilen tavan fiyat uygulamaları ve ara bağlantı ücretleri düzenlemesi diğer önemli düzenlemeler olarak sayılabilir. Bu sebeple sadece pazar payı dağılımındaki değişimi dikkate alarak 149 sayılı Karar'ın etkisini değerlendirmek mümkün değildir. Böyle bir değerlendirme için çok daha fazla veri gereksinimi olan ekonometrik çalışmalar ile nedensellik analizlerinin yapılması gerekmektedir. Fakat bu çalışma hali hazırda 149 sayılı Karar'ın uygulanmasının pazarda yarattığı etkiden ziyade, uygulamanın rekabetin sağlanması konusundaki potansiyel etkinliğini tartışmayı hedeflemiştir.

Görüleceği üzere düzenlemenin 7,5 yıl boyunca yürürlükte kaldığı kurguda, etkin piyasa gücüne sahip mobil işletmecinin tüketicilerin yanlılıklarını kullanarak kendisine rekabet avantajı sağlaması mümkündür. En basit haliyle, işletmecinin marjinal maliyeti neredeyse sıfır olan daha büyük hacimli paketler önererek hem net gelirlerini arttırması hem de tüketicilerin optimal olmayan tercihleri sebebiyle de kullanıma dayalı ortalama dakika başına şebeke

\footnotetext{
${ }^{19}$ Her bir yılın son çeyreğindeki veriler dikkate alınmıştır.
} 
ücretlerini fiiliyatta yükseltmeleri mümkündür. $\mathrm{Bu}$ durumun düzenleme gereği çağr1 sonlandırma ücretlerine yansıtılması ile de tarifeye dayalı şebeke etkilerin sürdürülmesi söz konusu olacaktır. Düzenlemenin bu etkileri hafifletme amacıyla yapıldığı düşünüldüğünde etkinsizliği görülebilecektir.

\section{SONUÇ VE DEĞERLENDİRME}

$\mathrm{Bu}$ çalışmada, tüketicileri salt rasyonel bireyler olarak varsayan sektöre özgü düzenlemelerin toplum için firsat maliyetleri yaratabileceğine vurgu yapılmaya çalışılmıştır. Bunu yaparken de BTK'nın 2009 yılında başlayıp 2016 yılında sonlandırılan ve kamuoyunda “149 sayılı Karar” olarak bilinen düzenlemesi üzerinden sistematik eleştiriler sunulmaya çalış1lmıştır. Giriş bölümünde de belirtildiği üzere bahsi geçen düzenleme, piyasada rekabeti tesis etmekte etkisi olmadığı gibi bir iddiayla değil, kullanıcıların algı ve yanlılıklarını göz ardı etmesi ve böylelikle firsat maliyeti yaratma potansiyeli olan bir düzenleme olması sebebiyle eleştirilmiştir.

Mobil iletişim pazarında etkin piyasa gücüne sahip olan işletmenin gücünü sınırlamak ve rekabeti arttırmak için çağrı sonlandırma ücretleri ile şebeke içi görüşme ücretleri arasında bağ kuran 149 saylı Karar'a dayalı düzenleme, uygulanışı açısından tüketicilerin algı ve yanlılıklarını dikkate almayan bir tasarıma sahiptir. Çalışmada, tüketicilerin kullanımına dayalı olarak işleyen uygulamanın iki yönüyle toplumsal açıdan fırsat maliyeti yaratabilme potansiyeli ortaya konmuştur. Bunların ilki, uygulamanın tüketicilerin optimal tercihlerini yansıtmamasıdır. İkincisi ise, düzenlemeye tabi olan işletmecinin tüketicilerin yanlılıklarından yararlanarak düzenlemedeki uygulamayı kendi lehine yönlendirebileceğinin gözden kaçırılmasıdır.

İncelenen vakaya özgü değerlendirmelerin dışında, sektörel düzenleyici otoritelerin tüketici refahını korumak ve rekabetin yerleşmesini sağlamak amacıyla yaptıkları düzenlemelerde davranışsal iktisat literatüründeki teorik ve ampirik çalışmaları dikkate alma gerekliliğini tekrar vurgulamak gerekir. Her ne kadar davranışsal teorilerin piyasa çıktıları üzerindeki etkilerini ayrıştırmak zor olsa da, kritik düzenlemelerin tasarımında küçük çaplı deneylerin yapılması önerilebilir. Böylelikle öncesinde çok daha az maliyete katlanarak sonrasında daha büyük sosyal maliyetlerin önüne geçilebilmesi mümkün olabilecektir. 
Genelleştirmek gerekirse, düzenlemelerin tasarımında davranışsal iktisat literatürünün dikkate alınması düzenleyici otoritelerin olası talep taraflı meseleleri daha kapsamlı bir şekilde ele almasını sağlama potansiyeline sahiptir. Davranışsal iktisat araçları henüz düzenlemelerin tasarımı konusunda doğrudan çözümler üretemiyor olsa da, sunduğu eleştiriler dikkate alındığı ölçüde düzenlemelerde etkinlik artışına yol açabilecektir. 


\section{KAYNAKÇA}

Ariely, D., Loewenstein, G., \& Prelec, D. (2003). “Coherent Arbitrariness”: Stable Demand Curves Without Stable Preferences. The Quarterly Journal of Economics, 118(1), 73-106. http://doi.org/10.1162/00335530360535153

Ariely, D., \& Wertenbroch, K. (2002). Procrastination, Deadlines, and Performance: Self-Control by Precommitment. Psychological Science, 13(3), 219-224. http://doi.org/10.1111/1467-9280.00441

Armstrong, M. (2008). Interactions between competition and consumer policy. In Competition Policy International (Vol. 4, pp. 97-147).

Atiyas, I., \& Doğan, P. (2007). When good intentions are not enough: Sequential entry and competition in the Turkish mobile industry. Telecommunications Policy, 31(8-9), 502-523. http://doi.org/10.1016/j.telpol.2007.05.012

Della Vigna, S., \& Malmendier, U. (2006). Paying Not to Go to the Gym. American Economic Review, 96(3), 694-719. http://doi.org/10.1257/aer.96.3.694

DellaVigna, S. (2009). Psychology and economics: Evidence from the field. Journal of Economic Literature, 47(2), 315-372. http://doi.org/10.1257/jel.47.2.315

DelVecchio, D., Krishnan, H. S., \& Smith, D. C. (2007). Cents or Percent? The Effects of Promotion Framing on Price Expectations and Choice. Journal of Marketing, 71(3), 158-170. http://doi.org/10.1509/jmkg.71.3.158

Frederick, S., Loewenstein, G., \& O’Donoghue, T. (2002). Time Discounting and Preference : A Critical Review. Journal of Economic Literature. http://doi.org/10.1126/science.151.3712.867-a

Gabrielsen, T. S., \& Vagstad, S. (2008). Why is on-net traffic cheaper than off-net traffic? Access markup as a collusive device. European Economic Review, 52(1), 99-115. http://doi.org/10.1016/j.euroecorev.2007.02.002

Gilovich, T., Vallone, R., \& Tversky, A. (1985). The hot hand in basketball: On the misperception of random sequences. Cognitive Psychology, 17(3), 295-314. http://doi.org/10.1016/0010-0285(85)90010-6

Grubb, M. D. (2009). Selling to overconfident consumers. American Economic Review, 99(5), $1770-1807$. http://doi.org/10.1257/aer.99.5.1770

Hsu, S. H., Huang, C. Y., \& Tang, C. T. (2007). Minimax play at wimbledon: Comment. American Economic Review. http://doi.org/10.1257/aer.97.1.517

Kahneman, D., \& Frederick, S. (2002). Representativeness revisted: Attribute substitution in intuitive judgement. Heuristics of Intuitive Judgment: Extensions and Applications. http://doi.org/10.1038/2251090a0

Kahneman, D., Knetsch, J. L., \& Thaler, R. H. (1990). Experimental Tests of the Endowment Effect and the Coase Theorem. Journal of Political Economy, 98(6), 1325-1348. http://doi.org/10.1086/261737

Kahneman, D., Knetsch, J. L., \& Thaler, R. H. (1991). Anomalies: The Endowment Effect, Loss Aversion, and Status Quo Bias. Journal of Economic Perspectives, 5(1), 193-206. http://doi.org/10.1257/jep.5.1.193

Kulalı, İ., \& Bilir, H. (2012). Türkiye GSM Pazarına Genel Bir Bakış: Şebeke Etkisi , Pazar Yapısı ve Sektörel Düzenlemeler. Süleyman Demirel Üniversitesi İktisadi ve İdari Bilimler Fakültesi Dergisi, 17(3), 415439.

Laffont, J.-J., Rey, P., \& Tirole, J. (1998). Network Competition: II. Price Discrimination. The RAND Journal of Economics, 29(1), 38. http://doi.org/10.2307/2555815

Laibson, D. (1997). Golden Eggs and Hyperbolic Discounting. The Quarterly Journal of Economics, 112(2), 443478. http://doi.org/10.1162/003355397555253

Lambrecht, A., \& Skiera, B. (2006). Paying Too Much and Being Happy About It: Existence, Causes, and Consequences of Tariff-Choice Biases. Journal of Marketing Research, 43(2), 212-223. http://doi.org/10.1509/jmkr.43.2.212

Levin, I. P., Wall, L. L., Dolezal, J. M., \& Norman, K. L. (1973). Differential weighting of positive and negative traits in impression formation as a function of prior exposure. Journal of Experimental Psychology, 97(1), 114-115. http://doi.org/10.1037/h0033846 
Li, S., Sun, Y., \& Wang, Y. (2007). 50\% Off or Buy One Get One Free? Frame Preference as a Function of Consumable Nature in Dairy Products. The Journal of Social Psychology, 147(4), 413-421. http://doi.org/10.3200/SOCP.147.4.413-422

López, Á. L., \& Rey, P. (2016). Foreclosing Competition Through High Access Charges and Price Discrimination. The Journal of Industrial Economics, 64(3), 436-465. http://doi.org/10.1111/joie.12115

Lunn, P. D. (2013). Telecommunications Consumers: A Behavioral Economic Analysis. Journal of Consumer Affairs, 47(1), 167-189. http://doi.org/10.1111/j.1745-6606.2012.01245.x

Miravete, E. J. (2003). Choosing the wrong calling plan? Ignorance and learning. American Economic Review. http://doi.org/10.1257/000282803321455304

Pauwels, K., \& Weiss, A. (2008). Moving from Free to Fee: How Online Firms Market to Change Their Business Model Successfully. Journal of Marketing, 72(3), 14-31. http://doi.org/10.1509/jmkg.72.3.14

Plott, C. R., \& Zeiler, K. (2005). The Willingness to Pay-Willingness to Accept Gap, the "Endowment Effect," Subject Misconceptions, and Experimental Procedures for Eliciting Valuations. American Economic Review, 95(3), 530-545. http://doi.org/10.1257/0002828054201387

Samuelson, W., \& Zeckhauser, R. (1988). Status quo bias in decision making. Journal of Risk and Uncertainty, 1(1), 7-59. http://doi.org/10.1007/BF00055564

Thaler, R. H. (1981). Some Empirical Evidence on Dynamic Inconsistency. Economic Letters. http://doi.org/10.1016/0165-1765(81)90067-7

Thaler, R. H., \& Shefrin, H. M. (1981). An Economic Theory of Self-Control. Journal of Political Economy, 89(2), 392-406. http://doi.org/10.1086/260971

Train, K. E., McFadden, D. L., \& Ben-Akiva, M. (1987). The Demand for Local Telephone Service: A Fully Discrete Model of Residential Calling Patterns and Service Choices. The RAND Journal of Economics, 18(1), 109-123. http://doi.org/10.2307/2555538

Tversky, A., \& Kahneman, D. (1971). Belief in the law of small numbers. Psychological Bulletin, 76(2), $105-110$. http://doi.org/10.1037/h0031322

Tversky, A., \& Kahneman, D. (1974). Judgment under Uncertainty: Heuristics and Biases. Science, 185(4157), 1124-1131. http://doi.org/10.1126/science.185.4157.1124

Tversky, A., \& Kahneman, D. (1981). The framing of decisions and the psychology of choice. Science, 211(4481), 453-458. http://doi.org/10.1126/science.7455683 